\title{
NOTAS DE LEITURA A UM CONTO DE GADDA
}

\section{Rodolfo Ilari}

Entre os atrativos mais fortes da personalidade literária de Carlo Emilio Gadda, costuma-se citar o aproveitamento, particularíssimo, das técnicas narrativas (de que se costuma apontar como exemplo Quel pasticciaccio brutto de via Merulana, romance policial falhado, intencionalmente, genialmente fa'hado) e a subversão do código verbal (de que seria um exemplo recente a reedição do Libro delle Favolle) Gostaríamos de prestar nossa homenagem póstuma ao escritor, lembrando que, embora as características acima apontadas sejam sobretudo valorizadas hoje, quando a crítica e a própria literatura assumem a crise por que passou a narrativa tradicional, e'as são bastante velhas na obra de Gadda e remontam pelo menos a Il castello di Udine.

Editado em 1934, quando Gadda tinha 40 anos e o fascismo 12. é inútil esperar de Il castello di Udine as drásticas atitudes antifascistas que caracterizarão mais tarde o ensaio Eros e Priapo e que foram um dos motivos de fama do autor; em relação aos problemas políticos Gadda adota aí uma posição menos comprometida e mais matizada: de um lado, cultiva um tema que os adeptos de D'Annunzio e o próprio fascismo erigiram em mito: o do sacrifício da guerra inútil, da vitória esvaziada e da pobreza de colônias e enfatiza (mas até onde vai a ironia?) o vigor e o espírito de sacrifício que o novo regime infundiu na raça; de outro lado, não hesita em transformar em matéria literária alguns dos problemas mais vexatórios do estado fascista, como o desemprego e a emigração.

Mas a quem se dispõe a ler esta obra das origens (que, pelo que sabemos, e contrariamente aos hábitos do autor não foi exp'orada a fundo para ree aboração e reedição posterior) está reservada uma importante surpresa de caráter especificamente literário: trata-se do tríptico "Polemiche e pace nel direttíssimo", notável pela utilização de uma linguagem aberta às contribuições mais heterôgeneas (linguagens técnicas, dialetos, língua arcaica) e sobretudo pela distância que o separa, na composição, tanto das notas autobiográficas que compōem outras passagens do libro, como da narrativa tradiciona!.

Primeiro escrito tipicamente ficcional, o último texto de $\mathrm{Il}$ castello di Udine é, talvez, o primeiro caso em que Gadda reage forte- 
mente à tradição narrativa: a reação traduz-se na aparente descontinuidade dos três capítulos - descontinuidade ao mesmo tempo cronológica (a $1 .{ }^{\mathrm{a}}$ parte situa-se historicamente na Idade Média, enquanto a $2 .^{\mathrm{a}}$ e $3 .^{\mathrm{a}}$ são contemporâneas), e lingüista (a língua do $1 .^{\circ}$ capítulo é arcaica ou pseudo-arcaica; a dos dois seguintes moderna, embora com a interpo ação de formas dialetais ao nível das personagens e com intenções conotativas)

A primeira parte, "La Chiesa Antica", é a história de um garoto romano: vadio, velhaco, que atormenta com suas pedradas os habitantes do bairro de Sant,Angelo e acaba por rivalizar com Pietro Fornaro, um padeiro de Tor Nona. Um duelo com este último deixa-lhe uma cicatriz em forma de cruz e a resolução de mudar de vida. Reencontramos ass $m$ o antigo garoto na carreira religiosa: padre, cardeal, e papa.

Da vida de Inocêncio II, Guadda seleciona episódios que o apresentam como adversário de reis e antipapas; por isso o leitor guarda a impressão de uma eixstência de utas e reveses. Há uma unica exceção: a consagração da basíl.ca de Santa Maria que, por ser enfeitada pelas pinturas de Petro Fornaro, e por abrigar a população romana antes dividida, simboliza a paz e a sobeania do papa sobre os súditos romanos. Mas à morte de Inocêncio, as disputas recomeçam: porque há dúvidas sobre o bairro que deverá abrigar-lhe o túmulo, porque na construção da basílica, que prossegue, os artistas discutem encarniçadamente as soluções ornamentais.

A conclusão dessa primeira parte é a enumeração caótica de uma série de passagens da história italiana: os mercadores de Legnano, a carnificina dos soldados de Garibaldi na batalha de Vascello, os religiosos do concílio de Trento, os mártires de Belfiore, Galileu, Giordano Bruno.

A segunda parte (Il fontanone in Montorio) começa pela alusão a um Signore Taciturno, que abandona misteriosamente o lápis com que estava escrevendo num compartimento de trem. Trata-se, verossimilmente, do autor da longa narrativa que compõe a primeira parte e, de qualquer maneira, todos os procedimentos de que Gadda lança mão em seguida para dar continuidade à narração têm nesse S.T um ponto de contacto, psicológico ou físico: há inicialmente um diálogo, travado entre o S.T e um desconhecido engenheiro hidráulico, que está voltando da Terra do Fogo, onde foi hostilizado pe'os técnicos locais; o diálogo evoca ao S.T outras viagens de trem, em que lhe foi dado ouvir as críticas dos passageiros à adm.nistração ferroviária. Depois de observar durante algum tempo o companheiro de viagem, o S.T adormece e sonha. Não há 
nexo entre as imagens do sonho; apenas alguns símbolos se destacam com nitidez: o dos operários, que cavam um enorme aqueduto para regar o Sahara, o do trem, que corre com combustível inglês, pago com as obras de arte da basílica de Santa Maria, sobre trilhos que se perdem na noite, sem destino. Ao acordar do sonho, o S.T medita uma frase de provável origem mussolinana: "la vita della mia gente è il perdurare di una fatica splendida, nel debattito di eterni contrasti" e acaba por aplicá-la às condições de trabalho dos trabalhadores da empresa que dirige. E assim, ficamos sabendo que o S.T dirige uma empresa de engenharia hidráulica, e que ele despedira na véspera um servente de pedreiro - Carlo Rusconi por haver esmurrado um companheiro de turma.

$\mathrm{Na}$ terceira e última parte (Sibili dentro le valli) a ação se condensa e precipita. O trem pára numa estaçãozinha da Uumbria. Entram no compartimento três intelectuais resfriados, e ali prosseguem sua polêmica verbal sobre conteudismo e ca'igrafismo. O S.T ouve e reflete. Mas a discussão interrompe-se com a entrada de um grupo de pessoas que carregam um jovem, acidentado ao descer do trem. Examinando os documentos do morto, os ferroviários verificam tratar-se de Carlo Rusconi.

O resumo que precede deve dar uma idéia razoável dos aspectos propriamente dramáticos da narrativa: em particular, dá conta corretamente da quebra existente entre a primeira e a segunda partes, mas sacrif.ca uma parte do tex o que se revelará de fundamental importância para a determinação dos níveis de enunciação e, através destes, para uma tentativa de recuperação da unidade do escrito. Como todos os textos de Il Castello di Udine, também "Polemiche e pace" é acompanhado por notas de rodapé, abundantes e extensas. A primeira dessas notas leva a assinatura de um Dr. Feo Averrois, que se declara incumbido da ingrata tarefa de tornar "meno oscuro ai piú chiari ingeni d'Italia il convoluto Eraclito di Via S. S.mpliciano" (isto é, o próprio Gadda) por meio de uma "traduzione che sará da poter essere considerata autorevole e valida. quanto consente almeno l'ambiguo de' di lui modi e processi" e levanta, pedantemente, uma "Sinossi delle abbreviazioni usate annotando"

Mas o grau mirabolante de liberdade com que o crít.co comenta as liberdades do autor, o tecnicismo engenheiresco de ambos, a linguagem igualmente trabalhada sugerem desde logo ao leitor que tudo, notas e texto, emana de um mesmo foco narrativo; em outras palavras, as notas são um recurso para enriquecer de determinações meta inguísticas (quando não de peripécias da ação) o texto principal; como diria um historiador da literatura italiana moderna, Fubini, trata-se de "variações" de Gadda sobre si mesmo, e Feo Averrois, heterônimo do escritor, não passa de uma invenção. 
Vale a pena realçar esse desdobramento de focos narrativos; não porque o desdobramento de focos é um procedimento recorrente da tradição épica e romanesca (pense-se no pape! fundamental que exerce desde a Odisséia), nem pelo fato circunstancial de que os resumos, comentários e notas de rodapé acompanham no curso médio a formação literária de todo estudante italiano, mas pelo papel pecul.ar que Gadda lhes reserva na estrutura deste conto.

Em primeiro lugar, é a partir das notas que podemos determinar com alguma precisão o valor semântico que Gadda atribui ao termo polêmica:

"Le quali polemiche si penserebbe il Ns. ne riconosca due classi: le necessarie poi le eleganti. Della prima classe son prima e seconda la polemica mangiativa e la generativa o genetica. Dele eleganti elegantissima è quella fra contenutisti e calligrafi, che tiene occupate da due anni (1931-1933) le lettere romane, non dirò le italiane" (200)

Em suma, Gadda abrange por meio do termo polemiche não só os debates orais e as discussōes abstratas, mas toda e qualquer situação de esforço e conflito, inclusive as provocadas por impulsos fundamentais, primitivos e concretos, como a fome e o sexo.

Entendida neste sentido amplo, a polêmica percorre todo o texto desde a primeira parte. Todas as intervenções de Inocêncio denunciam uma situação cońlitiva; e se a história de um papa do fim da luta das investiduras poderia limitar o alcance da observação às questões políticas, num período localizado da Idade Média, a lembrança de tantos episódios sangrentos da história italiana estende 0 problema ao campo ideológico, religioso e mesmo artístico. sugerindo a impressão de um progresso conturbado e iconoclasta.

A sequiência do texto não desmente essa impressão, mas acrescenta-lhe novas determinações: mudam as fersonagens, mas a relação dos homens com as coisas (por exemplo, dos operários com o objeto de seu trabalho) ou dos homens entre si (por exemplo, os operários que discutem e se esmurram) mantém-se essencia mente uma relação de conflito e contrastes.

A alternativa normal das polemicas, sugerida pelo próprio título, seria a paz. Mas o equilíbrio entre polêmica e paz, que o título também sugere, não se realiza: à polêmica, onipresente, a paz opõe-se apenas como aspiração, como situação momentânea. Por uma associação curiosa, mas que não é ta vez isolada na obra de Gadda, a paz coincide com a proteção materna: todos os passageiros do trem viajam para rever a mãe na noite de Natal; mas o Signo- 
re Taciturno percebe em sonho que o combustível do trem não basta para o retorno, ou que os trilhos se perdem ha noite sem destino; Carlo Rusconi tem sua viagem interrompida, e numa passagem da segunda parte diz-se textualmente que o seio materno não pode receber de volta os milhares de desempregados que morrem de fome.

E da impossib:lidade do retorno à fase psicanalítica da vida intra-uterina passa-se insensivelmente para o tema da paz como morte. O fim das lutas do papa Inocêncio coincide cronologicamente com sua morte; o termo paz é usado em vez de morte a essa altura da narração.

"Così, tra incendio e minacce, e dopo esilio e guerre, vide appressar la sua pace.

E o termo paz soa como morte à leitura, feita na presença do cadáver de Rusconi, do "pianeta della sorte" encontrado entre seus documentos:

"Dopo un forte dispiacere che vi daranno i vostri nemici e dopo avere ricevuto un forte colpo, finalmente troverete la pace in causa del vostro nobile cuore, il quale fu sempre assai nobile e dignitoso dell' onore, e dopo questa circostanza tutti vi lasceranno felice e tranquillo, e la Fortuna non cesserà più di proteggervi, specialmente se avrete giocato $29,7,14$ " (250).

Aceitar a dupla relação polêmica: vida $=$ paz: morte significa atribuir à polêmica caracteres de generalidade e, mais ainda, de necessidade. Observemos de passagem que isto condiz com a definição que Gadda-Feo Averrois dera da Gadda-escritor: um dos princípios mais lembrados da filosofia de Heráclito era precisamente a afirmação de que "a guerra é rei e pai de todas as coisas", ou seja, de que as coisas resultam materia mente da composição dos contrários.

Assumindo ou desenvolvendo a autodefinição ("Il convoluto Eraclito di via S.Simpliciano") Gadda cria uma narrativa rica em situações conflitivas (procuramos apontar as principais no resumo) e em objetos de valor ambíguo (pense-se em todas as "construções" do texto, desde a Basílica de Santa Maria até os aquedutos e as centrais hidrelétricas), uma constante que pode ser valorizada como poderoso fator de unidade.

Mas há outro princípio heracliteano cuja exp'icitação é provavelmente intencional neste texto: é a tese do panta rei, traduzida numa classe de símbolos que criam a impressão de um envolvimento num processo urgente e irreversível: enquanto Gadja narra, um 
tempo irrecuperável se escoa. Na primeira parte, o passar do tempo é indicado por sons repetidos em cadência, como as batidas do martelo na bigorna ou o canto das cigarras que servem de música de fundo à infância do futuro papa Inocêncio (" . stava come stornito ad ascoltar le cicale. intanto che il martello, di S. Benedetto, batteva e attuffava, attuffava e batteva, per consumar bene le tristi ore, le ore del tempo" (205) "E mentre il fornaro ripetè il colpo più forte, ogni cosa gli si oscuró nella testa quaiscchè l'incudine si fosse taciuto di subito con tutte le cicale del mondo. Era notte dove tutto tace" (204) Nas partes seguintes será o trem, que atravessa a tempestade noturna sem encontrar sinais vermelhos, e arrasta implacável seus passageiros até uma vaga estação da Itália do norte (Milão) o símbolo do continuum temporal, como confirmam várias alusões:

"Il treno corse via traverso l'Italia. Nè fuochista nè macchinista si diedero pace piú. Vampe rosse, dal boccaforno, irradiarono ad ogni palata il loro aligo fuggente nella fuggente notte (...) Anni andati! Piú celere aveva corso l'inesorabile traverso l'Italia e il mondo, piú che il diretto a Sarzana. Vi erano armi ne'la patria dei meravigliosi poemi" (220).

"Cosí pensava il Signore Taciturno benché avesse quarant" anni, quei famosi quarant'anni che G.B. Angioletti gli aveva attribuito due anni prima" - "Nel 1931 (dicembre) il Ns. aveva diciotto anni. G.B. Angioletti aveva arrotondato la cifra, dando una spintarella al direttissimo" (227,227 nota)

Aproveitando sugestões das notas de rodapé - em particular aque'as que comparam ironicamente o autor com o filosófo de Efeso, conseguimos apontar, num texto onde os elementos narrativos nos desorientavam, dois poderosos fatores de unidade: o primeiro é a generalização de situações conflitivas. como se o autor, em vez de resolver conflitos já expostos (segundo os preceitos da gramática narrativa trad cional), andasse em busca de novos, prolongando assim a exposição de sua obra numa espira' indefinida. O outro é um procedimento de conservação, pelo qual o autor respeita, na diversidade das situações evocadas, certas constantes temáticas como a s:mbologia da água, da construção, do tempo.

Poderíamos analisar em detalhe o tratamento dado a estes motivos mas preferimos, nesta nota, limitar-nos a algumas constataçōes imediatas, lembrando que as observações acima, além de dar conta do título, correspondem de maneira precisa a uma constatação, fejta por Gadda-Feo Averrois, segundo a qual

"Vincolo ideale fra le due (partes) non direi essere il procedimento di effetto da causa, ma una persistenza lirica in cui 
la nostra immaginativa si consuma, con un vago senso di labilità e di superstiziosa irrealtà" (199).

Não é preciso dizer que essa intuição de Gadda va'e para o conto como um todo, e que a oposição entre "relação causal" e "persistência lírica" define uma das oposições possíveis entre narrativa tradicional e quanto, em 1930, podia ser qualificado de vanguarda: uma alernativa e uma o oção que, ressalvada a especificidade dos dois processos de criação, lembram a opção do músico entre sinfonia (desenvolvimento preso a uma estrutura rígida, a partir de um tema) e suite (liberdade temática e persistência de características tonais)

Nas observações que precedem utilizamos algumas das indicações fornecidas pela personagem Feo Averrois como pistas para uma interpretação global do conto. Isto bastaria, numa gramática narrativa tradicional, a justificar a existência dessa personagem, que se encarregaria assim de ser o porta-voz do autor. Mas à parte os riscos que sempre se correm em identificações sumárias desse tipo, creio que a invenção do crítico desempenha, na economia do texto, um papel bem mais central.

Com a invenção do crítico, o escritor passa a dispor de três níveis narrativos distintos, que se encaixam uns nos outros por um fenômeno típico de transposição de enunciações: cada um desses níveis cria um foco narrativo próprio, que se corporifica num sujeito enunciante ou num grupo de sujeitos enunciantes. Verificamos assim que toda a primeira parte é o longo exercício literário de uma personagem da segunda e terceira: o Signore Taciturno; a narração da $2 .^{\mathrm{a}} \mathrm{e} 3 .^{\mathrm{a}}$ partes, quando não surge através de diálogos ou lembranças, é emanação de um "autor" nomeado, segundo o apelativo tradicional da crítica de texto italiana "Il Nostro" (= o A.); e é sobre esses dois níveis inferiores (entendidos globalmente como a produção de Il Nostro) que se pronuncia o crítico Feo Averrois: uma situação que poderíamos esquematizar como segue: 


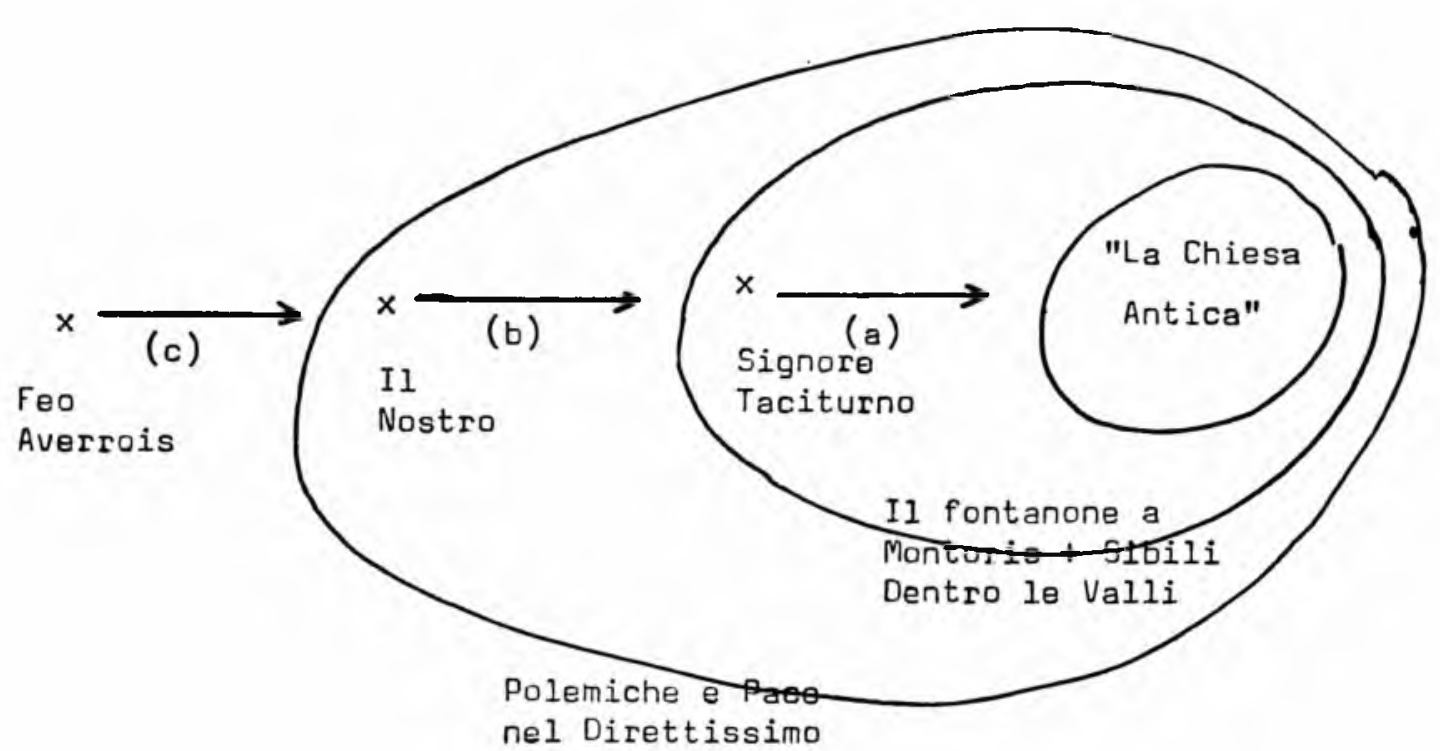

Como em todos os esquemas didáticos, não faltam no que precede simplificações e distorções: é evidente, por exemplo, que o sentıdo a atribuir as três flechas (a) (b) e (c) não é o mesmo (nos casos (a) e (b) a flecha indicaria grosso modo a relação "ser o narrador de"; no caso de (c) a relação suposta é de meta inguagem para linguagem objeto); é claro também que os casos de enunciação aí apontados o foram com o objetivo de exemplificar níveis, e não de enumerar todos os casos observados (que são mais frequientes e estranhos do que poderia parecer à primeira leitura - como atos de enunciação devem ser contados, por exemplo, a ocorrência do acidente de que foi vítima o pedreiro, que o chefe de trem lavra com meticulosa diligência; além do "pianeta della sorte" e do cartão de votos nata inos encontrados na carteira de Rusconi: observese como, em todos estes exemplos, são preponderantes as enunciações que adotam um veículo escrito, introduzindo uma narrativa escrita na narrativa escrita)

Ademais, a distinção desses três níveis perde toda rigidez, ao verificarmos não só que os três enunciantes principais são heterônimos circunstanciais de uma personalidade única (a de Gadda escritor), mas ainda que, através do diálogo dos três críticos resfrados, um discurso "crítico" se instaura também ao nível (a), o que s:gnifica fazer do crítico mais uma personagem, e movimentar os trếs níveis por um processo de circulação contínua.

Mas o esquema proposto revela-se útil além da simples localização e de uma eventual modalização dos atos de enunciação quando, superposto à indefinida enumeração de situações conflitivas de que falamos. permite verificar que essas situações se dispõem segundo uma hierarquia precisa: há conflitos nos três níveis, embora, quantitativamente, os do nível (a) pareçam preponderantes. 
Ao nível dos debates críticos, põe-se o conflito entre o realismo rasteiro de tipo jornalístico e folhetinesco (contenutismo) e o formalismo de superfície (calligraf.smo), um conf ito que foi profundamente sentido pelos escritores italianos da primeira metade do século, e que as óbvias limitações políticas impostas à literatura no ventennio fascista resolveram artificialmente em favor do caligrafismo, como !embra Moravia num ensaio de 1946 ("Assenza di maestri", novamente publicado em L'uomo come fine)

Inserida nesta polêmica literária, a composição de Polemiche $e$ pace nel direttissimo não é mais um ato gratuito: diz-nos o comentarista de nome árabe que foi estímulo negativo desse trabalho de Il Nostro o não ter obtido anos antes um prêmio literário, acusado que foi por outro escritor (e este é real) de ter incorrido no pecado sem remissão de ser "literário" (no sentido depreciativo do termo, ou seja caligrafista) Portanto. pareceria óbvio procurar em Polemiche e pace uma resposta à acusação de Angioletti: profissão de fé caligrafista ou conversão declarada ao conteudismo. Mas como classificar o ponto em uma ou outra rubrica?

Toda a primeira parte - situada no passado e caracterizada pelo virtuosismo verbal do escrevente (calligrafismo) choca-se (Gadda-Feo Averrois usa o verbo accozzare) com as seguintes, que parecem impregnadas de problemas contemporâneos e reais, e comunicam a simpatia do escritor para com as principais vítimas da situação vigente; nas últimas duas partes, aliás, multip'icam-se as coincidências de sabor novelesco (pense-se no reencontro do S.gnore Taciturno com o operário Rusconi; ou no "pianeta della sorte" encontrado entre os papéis deste último, onde tudo coincide com a situação, desde o dispiacere e o colpo, até os números sugeridos para uma aposta na loteria nacional, que batem com as datas de nascimento do acidentado. ); e isto poderia ser interpretado como um sinal de conteudismo. Como decidir?

A intenção última de Gadda, neste conto, parece justamente ter sido a de eludir por um tour de force esta incômoda dicotomia: há, é verdade, em Polemiche e Pace momentos realistas e momentos de minuciosa elaboração estilística, mas as páginas mais extremadas num e noutro sentido Gad Ja não as reivindica para si, senão para heterônimos como o Signore Taciturno ou o chefe de trem a redig.r a ocorrência; ao mesmo tempo que ridiculariza o crítico, maldosamente rebaixado à inařrelável situação de personagem, atribuindolhe um discurso fútil e contraditório.

Com este paradoxal jogo de ficções, torna-se mesmo impossível ir além da dúvida se seriam sentimentos autênticos ou ficções os sentimentos que a narrativa transmite em relação às situações vivi- 
das pelas personagens (se o fizéssemos, estaríamos optando por uma leitura "conteudista"); é por este preço que Gadda evita (e transcende) a alternativa imposta pela crítica de seu momento, mantendo o debate em aberto.

Podemos encarar este fato positiva ou negativamente, acusando Gadda de indefinição e alienação, ou valorizando sua descoberta da "abertura" Podemos, aliás, adotar as duas conclusões contraditórias ao mesmo tempo - aplicando ao próprio conto de Gadda o princípio nele exposto, segundo o qual as construções humanas perpetuam e revelam contrad.ções. O que parece difícil para o crítico, de qua quer forma. é aplicar-se ao conto numa situação diferente da que o próprio conto prevê: qualquer observação que façamos, prolonga as intermináveis (e estéreis) tergiversações dos críticos resfriados do compartimento de trem. Gadda joga aqui sua última carta e seu maior trunfo, ao declarar-nos descaradamente que a interpretação de seu escrito não pode ultrapassar os limites do próprio escrito - porque as alternativas de interpretação já estão nele previstas, e porque a própria figura do crítico já vem nele estigmatizada pela marca da futilidade e da esterilidade.

Dóceis intérpretes, podemos corporificar a gosto essas personagens gaddianas, se isto nos agrada. Os riscos põem-se em outra dimensão: o tempo que - como no cé ebre verso das Geórgicas se escoa irrecuperável. 


\section{O FONTALHĀO EM MONTORIO}

Carregadores e malas no corredor. Todos subiam.O caderno foi fechado, a mão do escrevente, já sem lápis, pareceu cansada. Talvez o esboço de um romance histórico: ou um exercício de caligrafia, ou um garrancho bigodudo como o rabisco que tem no bloco das folhas, no telefone (1)

"Se pudéssemos descansar pelo menos na noite de Natal!... Paz aos homens. (era um bocejo) de oa ontade Queremos apagar a luz?"

"Talvez" opinou o senhor taciturno ao guardar o caderno; mas talvez seja me'hor não criar suspeitas a inveja afina o cérebro aos cães de trufas.

Seu interlocutor bonacheirão parecęu ter falado de boca cheia, ou como se o bocejo não estivesse dominado de todo. Então observou-o. Um tique voluteava-lhe dentro da máquina dos ombros e do pescoço. A harmonia jovial de sua carantona e de suas mandíbulas inchadas (aparentemente cheias de nhoques e de caroços de ameixas) descrevia no espaço uma sucessão interrompida de trajetórias arqueadas (2), de quarto grau. A característica geométrica desta família de curvas era discernível de pronto, mesmo ao mais pnofundo dos intimistas. Não se tratava, porém, de uma regressão psíquica, mas de um simples tique.

O senhor taciturno, aos poucos, conheceu que este seu companheiro de viagem era novarês porque, o horário à mão. lhe documentou até depois de Monterotondo a falta de boas ba deações novarenses nas estações de Milão, nova e tresvelha.

Vinha da ilha do fogo e da terra do sol, onde os engenheiros locais (assim disse), lhe haviam sagazmente envenenado uns tantos orçamentos seus de aquedutos, redigidos com a mais solícita diligência, com a mais consumada perícia.

(1). - O senhor taciturno é suspeito de caligrafismo.

(2). - "Curvas arqueadas" são as que evoluem no espaço: (p. ex. a espiral cilíndrica): t. matemático que se contrapõe a "curvas planas", descritíveis num só plano (p. ex. a hipérbola). 
Culpavam-no por não ser um engenheiro local: e diziam (enquanto sua carantona novaresa continuava a vo.utear-lhes em frenao nariz):

"Não há engenheiros aqui também? Pitágoras, pela Madona, não nasceu nas margens do Sésia e do Ticino. Arquimedes não foi amamentado em Varallo" (Os dentes branquíssimos relampagueavam, e os olhos, num lampejo acre) "E Empédocles, para reencontrar "seu" fogo, não se at rou das escarpas do Cástor (3) mas, transposta a alta margem, no abismo de Encélado, de onde fumega e onde referve o sangue. o sangue em brasa do mundo"

A idéia de ficar só no escuro com o homem dos aquedutos (noite adentro! até que o viaduto de Rogoredo the aparecesse entre neblinas, em sua beleza estuco-cementício-f oral, regatada por regatinhos côr de fossa) aquela idéia ao senhor taciturno lhe fez lembrar outra viagem, onde estavam apinhados em oito com lâmpada b eu queimada: próxima no lugar foi-lhe a dama um tanto magra, presumivelmente loira, de voz cordata e como que jaspeada de harmoniosas esperanças.

Nascera um grande discurso acerca de peras queimadas: (4) e outro sobre o calor e o frio, porque a barra, co.ocada no "frio" dava ainda mais calor que no "calor" Intmada a comparecer, a Direção Geral das Estradas de Ferro não tivera modo de justificarse, alvejada pelos mais sibilantes sarcasmos, até que aqueles se haviam adormecido em bloco: e, acordados depois em a amanhã ante Fidenza, descobr.u-se que, girando-a um pouco, a lampadinha ressuscitava. Quanto ao calor, já havia um pedaço que virara um calor um pouco frio demais. ". .é estamos mais para o Norte. ", acordaram unânimes. Remanobrada a alavanca, estavam quase a ponto de achar que a Direção Geral das Estradas de Ferro não é lá trouxa de todo mas, como bons italianos, contiveramse em tempo (5)

Ele, mal descido da descida de são Lourenço, enquanto o comboio se punha a correr sob as luzes de Campo Verano, entrara a compor uma tal montanha de capotes e cachecóis sobre os joelhos que aqueles, só de vê-la, haviam navegado em suor, com gotejamento nas têmporas e os olhos extremamente diatados.

(3) - No maciço do monte Rosa.

(4) - Peras = lampadinhas elétricas.

(5) - Mor.: insuportável para o A. já em 1910-12 o ceticismo tapado e a sapienciazinha resmungosa dos concidadões, sintoma não de força mas de cansaço moral. 
Não compreendiam. Ele olhava obstindo pela janela, como se fora, no escuro se visse algum cavalo. Enquanto isso fora-lhe dado o que mais the ardia: não abrir o bico. Depois, durante o enfurecer da filípica, estendera o montão aos jiolhos da senhora, com jeito de ing'ês gélido, que atende impecável a seus deveres estilísticos.

Sorru de si, na lembrança. Depois, todos adormeceram: alguns pareciam ter uma ervilha seca no veubadalo, e emitiram de quando em vez si'vos ou uma espécie de trilado, como os caçadores de pássaros, na caça.

O trem correu chão afora através da Itália. Nem o foguista nem o maquinista se deram paz mais. Labaredas vermelhas, da boca-forno, irradiaram a cada pá seu hálito fugaz na fugaz noite. Sob o cúmulo dos capotes, e dos chales, a senhora respirava numa doura submissa, às vezes com um sobressa'to ou um staccato, como uma adolescente maravilhada.

Anos idos! Mais rápido correra o inexorável (6) pela Itália afora e o mundo. mais que o rápido por Sarzana. Havia armas, na pátria dos maravilhosos poemas.

Agora o novarense tirara o paletó, que deu prova do sol e do mar da Itália, se pudera despintar-se até tão perfeita neutralidade. E fazia menção de tirar os sapatos. Um lampejo de inquietação atravessou o cérebro do senhor taciturno, desapareceu. " .Insta'ações hidrálicas. Velho Piemonte. Parece que vamos indo bem. " concluiu serenado.

“ contanto que os cães trufeiros nos deixem em paz. E Natal! Quem diabo deveria subir? Teròntola, quem sabe.." monologava; "ou Arezzo.. uma velha inglesa, regressando de Vernia em Lungarno, completamente empergaminhada. Esperemos que esteja em fase de penitências, que assim ficará de pé no corredor, a esperar a morte. irmã nossa morte. irmã Batebota!

Pois sim! Pois é! Oh! E! Isso mesmo!

O hidráulico tinha tirado os sapatios. O senhor intuiu tal perfeitamente. Os olhos. a exemp'o do nariz, dilataram-se-lhe na certeza. Nenhuma dúvida.

O hidráulico pusera os pés e respectivas meias sobre o assento, desejou boa noite: virou-se, revirou-se, parecia que o tique se lhe

(6) - O inexorável é o destino, comportado pelo tempo. À mania dos resmungamentos sucedera, inclusive nos trens, um espírito novo, fascibus restitutis. Por Sarzana o rápido de Milão n. ${ }^{\circ} 16$, que não é o do conto, mas é ainda assim freqüentadíssimo pelos milaneses. Sarzana é uma alusão trágica, sublinhada pela continuação: "Havia armas etc." 
houvesse transferido da máquina do pescoço para aquela outra máquina e o que rodava não era mais a cara onde tem os olhos, mas a outra cara. (7)

A toda modificação de deitadura, as molas do divã coaxavam e rangiam sem conforto, o pensamento corria por instinto à Villa Patrizi, ao Provedor Geral, a sua dedicação integérrima; oh! Divisão do material rolante, Secção manutenção, sub-secção assentos, repartị̧ão amolecimentos!. Aquele salame onírico comprometia a babança da Empresa, minava a paridade.

A encrenca maior, porém contudo, eram ainda sempre as meias: e o respectivo conteúdo.

"Com os ra.os os aquedutos!" pensou o senhor taciturno soando o nariz: "Com os raios o conteúdo!" Contou e recontou, na claridade azulada, os cinco buracos da esquerda. As plantas pareciam solas, a tal ponto imitavam as sombras e a rigidez seca do couro.

"Longe da mamãe. no mundo hostil. privo de dutos adequados. onde comanda o deus da luz, que é a um tempo deus do calor, e pois do suor. Oh! a acumulação de cargos!" (8)

Intuia agora. com as pálpebras pesadas, por que C'áudio, imperador e truscólogo, pudesse ter pensado inclusive nesse negócio. A fonte de Trevi e o fontalhão de Papa Paulo apareciam-lhe, no sono superveniente, magnas conjunções de sob?rbos pensamentos, maravilhas esplêndidas de arcos, de tritões de rios devertidos, que tais o santo padroeiro de Gorgonzola (9) não ousaria sequer crer concebíve.s obras.

E sob o torvo vaporar das nuvens havia fugas de pilares e de arcos. Mas passe! Não havia somente bombas e tubos Mannesmann no transfigurável mundo, curvas de 6 polegadas, reduções de três para dois, registros de quatro. nip es de oito. Cem fístulas, todas quinárias, encomendou o cardeal na euforia, e mais mil, do que abeberar as plantas aos ciprestes (10) Depois havia uma longa, detrás.

(7). - Quem se resolve no leito, alça rodando a grande máquina do cia.

(8). - Referido a Foibos, fúlgido senhor da Grécia e da Magna Gré-

(9) - Deselegante alusão, com bisenso, aos insuperados produtos caseários que derivam seu nome daquela terra. Gulosos a quem quer que fosse, o A. os rejeita, temperamental.

(10) . - Segundo o P.Bergamoni é um não-senso. Para Antônio Massa e Calímaco Bresciani tratar-se-ia de um amontoado de palavras em liberdade, representativas do delírio onírico, o que exclui Horaessa. Grühauer, Weiningen e Schultze ao contrário, vislumbrem nisso uma precisa alusão à 
infindável trincheira, e nela labutavam de enxada e picareta as matilhas dos sem-camisa, para aí depor o grão tubo de regar o Sahara. (11)

Pronto! o maquinista depusera no forno três poliedros negros, de um raro elemento: alguns ingleses com por chefe lord Strickland lhos haviam cedido em troca da Virgem das Rochas (12) Mas as três peças não chegavam pra chegar a Milão, rever a mãe (13) Lord Strickland ia dar mais peças, mas queria a Natividade, a Epifania e o Transitus. E Pietro Cavallini, noite adentro, noite e noite, trabalhava de acabar; o colo estava feito; em sua doçura, o regaço materno achava repouso.

Quem entrava na igreja? Quem nela rezava? Na Noite de Nata', as criaturas dorando nascem, e voltam outras da guerra, ou do exílio. Coros de anjos cantam, pela doçura de toda mãe agraciada.

Mas era vã a corrida, os trilhos não aportavam à Estação (14) como outrora: à sua frente, negra e infinita, só a noite se abria: ausentes os rostos e as vozes do carro vazio, toda esperança, toda mulher

Verde Lombardia coroada de neves! O exército de Radetzki desapareceu atrás das cascalheiras dos erráticos rios; cs enforcajos tiveram túmulo; e das soberbas centrais se desprendem b:lhões de kilowatts-horas, a um e noventa cada, taxas incluidas. Os excelsos

villa do cardeal de Este em Tíbur, e assim traduzem: "O cardeal (Hipólito Segundo de Este, 1509-1572) encomendou aos fonteiros a fonte das cem bicas e os jogos todos do formoso jardim: mas a frescura da água sacia a sede às raizes dos ciprestes" (Piante, it. cláss. = piedi) Os dois números lembram Catulo, Carm, V-7: "...mille, deinde centum" a qualidade das árvores a Horácio Carm. II, XIV, 22-24: " . Neque harumquas colis arborum - Te praeter invisas cupressus - u!la brevem dominum sequetur"

A "fiscula quinaria" constituiu o padrão de distribuição romana: adotada provavelmente durante o mandato de Agripa, corresponde ao nosso tubo de $7 / 8$ de polegada.

(11). - Dolorosa e raivosa alusão a $\mathrm{n}$. pobreza de colônias. Em antítese com o Sahara, as "mutidōes de sem-camisas"

(12) - Da "Vierge aux rochers", bem sabes, duas versões: a parisiensis do Louvre, demão mestra, e a segunda na National Gallery, de mão mestra e discípula (Leonardo com João Ambrósio Preda) A qual última, pintada durante o segundo "período milanês" para a Capela da Conceição em São Francisco à Porta Vercelina, foi adquirida em 1796 por Gavin Hamilton, herdada pelos Suffolk, legada à N.G. Foi objeto de conhecido litígio civil entre Leonardo, Preda e os comitentes.

(13) - E a noite de 24-25 dezembro. Cada qual tem o pensamento voltado para a mãe. Lord Strickland é o governador de Malta.

(14) - O recente deslocamento da estação central de Milão (julho de 1931) deforma-se no sonho numa misteriosa causa de angústia. O sonho é autêntico. 
eletrobombos, depois da refeição, dignam-se cedê-los aos incompetentes por tão tênue moeda. Coisa de não crer. As turbinas giram, giram; de vez em quando acha-se que foi parar !á dentro uma truta, ou uma enguia (15)

Novamente acordado, viu que os outros continuavam a alinharse em sua fuga noturna, as bielas transmudavam em impulso o impulso (16), a orçada corrida não negava os verdes cículos anuentes, à passagem dos semáfonos solitários.

E as trufas (17), desta vez, tinham espantado os cães.

Voltou a meditar o que o sono lhe lembrara: "A vida da minha gente", disse consigo" é o perdurar de uma fad'ga esplêndida, no debate de eternos contrastes"

"Estes contrastes", haviam gritado em seus tímpanos "enquanto contrastes de pensamento, podiam passar sem a gramática. Para cavar trincheiras aos encanamentos e regar palmeiras e jardins no estuante cerco dos muros, que necessidade havia da gramática? Bastava a picareta.

Bastava a "human:dade" das personagens gotejantes sob o látego de Agosto: a humanidade de Gigge', de A'fre', de Arrighe' de Peppi', de suas sacro-santas fatroas, de seus camaradas de armas desempregados, e de sua filharada global.

Entrementes, à espera da água milagrosa (18), por sorte que havia um que rodava com um balde e uma caneca; e quem tinha sede bebia. De quando em vez tropeçava nos canos ele o balde e a caneca, e iam os três parar na fossa.

Depois, a alegre sirene trazia-lhes um pão, um filão, como dizem: enquanto o palpitar do conteúdo (19) começava a reavivar as fortunas da Patria. Balzac e Dostoiewski já estavam a caminho.

(15) - Isto não é de todo raro, sobretudo nas centrais de pequena

(16) - Não trocadilho, mas expressão rigorosa: "traduziam o impulso retilíneo alternado em impulso rotativo". Esta é a função dos manivelismos. "Os verdes círculos anuentes. "= Os sinais abertos.

(17). - Deselegarte alusão ao cheiro que se produz por vezes nos compartimentos de trens por efeito da falta de diligência ou da falta de modos de algum dos passageiros. Os "cães": taes para quem se propôs dormir um bom sono os passageiros que sobem nas estações intermediárias, e lidam de achar onde achar lugar.

(18). - Al. a um hipotético trabalho de contudar águas. "Os muros" da Urbe ou de um grande parque, ou de um hipotético jardim.

(19) - O "filãozinho" é recheado pelo recheio, à guisa de sandwich . "Palpitar" por metonímia. A vibração é toda de quem vai pôr-lhe o dente. O conteúdo, isto é, o recheio, reaviva as fortunas da pátria na medida que confere vigor aos moços. "Saco vazio não pára em pé" dizia Napoleão. 
$\mathrm{Na}$ expectativa de que Eugénie Grandet reso'vesse casar com o hidráulico e remendar-lhes as meias (mas não lavá-las, por obséquio, não resvalemos na "literatura") eis que a quarta Itália estava recuperando finalmente seu século, e sua "tragédia" Depois da incubação do poema-heróico, depois da gestação da "Mérope", quatro e duzentos anos após, eis outro grande parto à vista. Parturiunt montes! "Dessa vez porém, tirante a retórica, nascerá. uma tintureira"

"E se ficarem bonzinhos será manca"

Será a Maria Timofeievna Stavròghina da rua do Império, acabará como a florista, demente e esfarrapada, esposa do príncipe, esfaqueada pelo galeote. Os rubios da chac.na nós nos arranjaríamos para traduzi-los em liras. Nós jovens.

Assim pensava o senhor taciturno, muito embora tivesse quarenta anos. aqueles famosos quarenta anos que G.B. Angioletti lhe atribuíra do.s anos antes, em vez do prêmio (20)"

Tinha cheios os tímpanos da dialética dos opostos partidos (21) mas o Fontalhão de Papa Paulo estrovertia seu rio jocundo contra as serenas luzes albanas (22), quando as estre as empalidecem sobre o tempo de Vênus, sobre a cúria de César; artigo e insigne calígrafo.

\author{
Paulus Quintus Pontifex Maximus \\ Aquam in Agro Bracc.anensi \\ Saluberrimis e Fontibus Collectam \\ Veter.bus Aquae Alsietinae \\ Ductibus Restitutis \\ Novisque Additis \\ XXXV Ab Miliario Duxit.
}

Paulus Burghesius, de águia, e dragão.

Dos montes sacrificais a luz resfulgura: averme ha os anjos no alto e depois, pouco a pouco, as duas qualidades das bestas burguêsias (23) Cintila o derramado rio rubis e topázios. Então Pep-

(20) - Em 1931 (dezembro) o A. tinha 18 anos. G.B. Angioletti arredondara a cifra, empurrando de leve o rápido. " .o prêmio. " da Itália literária 1931 .

(21) - Ou seja calígrafos e conteudistas, no polêmico biênio romano (1931-1933 e ss.). Mas o fontalhão se lixa pra isso.

(22) . - A corredeira do fontalhão olha de quase frente os montes de Tíbur e Preneste, os Sabinos mais para Norte, os Albanos a Suleste: entre que o Monte Cavo, que é o Monte Sacrifical, o "mons" por antonomásia.

(23). - O emblema dos príncipes Borghese (lat. Burghesii) é bipartido por uma horizontal em dois campos: de que o superior ocupa a águia e o dracão o inferior. A fonte de Paulo $V$ é ornada de águias e dragões. 
pi' e Gigge' soem levantar-se e lavar-se, e, engolido o café-leite, vão construir os aquedutos. Lavam-se com alguma alegreza, e não só as mãos. Da água, escorre por terra, um pouco por toda parte.

O santo padroeiro de Gorgonzola, ei-'o que ficou com um palmo de tromba.

E porém, como personagens, eles são personagens falhadas. Não vêem? Essas abluções os desumanizam.

Seria como alguém que quisesse escrever uma obra-prima e investisse nisso, ao contrário, a língua italiana. O senhor taciturno sacudia hamleticamente a cabeça: "Literatura, literatura!" (24)

Um notável toque de humanidade parecera-lhe ter ao contrário aqueloutro, o Rusconi, que na tarde anterior se lhe apresentara no barraco com um chapéu na mão. digno realmente do eminente Dostoievski de Praça Pollarola (25) Havia cerca de dois meses, o pobre diabo trabalhava de picareta e enxada na lama de seu fosso, mais fundo que um observatório do Exército. Dez horas por dia. Uma bela agüinha cerúlea, da cor da que chove das mãos às lavadeiras, quando torcem o pescoço acs seus lençóis, esperava-o toda manhã no fundo: e eram sete horas na batata.

Uma linda bomba centrífuga (oh! que jóia) fingia facilitar-lhe a vida. E arre com baldes de lama! que, em sua preocupação em não incorrer em caligrafismo, chamava "Sidei de palta" Daí a pouco, por mais que trabalhasse no fresco, tirava o paletó: depois também o co ete, de uma cor de rabo de sardão: e a malha ensopada parecia então um mapa das Ilhas do Cabo Verde, depois das primeiras anotações de Alvise Cadamosto.

Assim, sua mulher e filhos, e todos, em família, comiam. Uma saca de arroz de primeira, "agulhão" legítimo chegava-lhe cada mês das suas banłas, ' $d$ ' i me sit", que eram bandas entre Sadriano e Magenta, bem no rumo de Novara. Mal recebido o aviso, e com licença dos superiores, fazia-se emprestar um carrinho de mão e num relâmpago pelo Muro Torto o tinha empurrado até San Lorenzo (26) e desembaraçado sua saca. Cidadão exemp ar sob to-

(24). - " . Hamleticamente..." com significado insólito = com fêz Hamleto, exclamando: "literatura, literatura!"

(25). - O A. alude jocosamente a si próprio e a sua mania de andar pelas aí, por certos becos e vielas. Há, ademais, um ar de iminência em toda a narrativa italiana, mas o esperado Dostoievisqui ainda não apareceu.

(26) - Terminal de carga. Estação de cargas em G.V 
dos os ângulos, crescia os filhos no culto do agulhão, e celebrava o dia do arnoz trezentas-e-sessenta-e-cinco vezes ao ano.

Recolhida, às sombras da noite, sua gente à mesa, sopravam os oito uníssonos sobre a colher, bem anuentes os Penates, na comunhão caldosa da janta. A sopa fumegava, humaníssima (27)

As senhoritas pedajutórias, essas custava um pouco a tragá-las. - "Cinco liras, cavalheiro.

Saía como mirrado e encompridado de seu fosso, como se o crescer das águas freáticas o houvesse induzido a crescer um pouco, ele também, de níve'; tinha armado o observatório com uma audácia poderosa, que fosse uma escavação de sustentar seis filhos, não de f.car soterrado. Tirava as botas; depois de ter apalpado um pcuco as grossas meias de lã, metia os sapatos, "arregaçava" as calças, lavava-se lentamente, na torneira perto do barraco, sem queixar-se a ninguém, nem ao Padre Eterno.

Achava que os aquedutos são idéia grande, e necessária a um grande povo. Mas o senhor taciturno tinha razões para suspeitar que, a ém do fluxo dos aquedutos, também o resíduo da tradição albana não fosse algo de todo alheio a seu espírıto. Certas tardes via-o sair do profundo, com uma cara! (parecia um peru), e dois o hinhos.

Então não tinha je.to de arrancar-lhe uma só sílaba, nem um cumprimento hierárquico. Era mais mulo que o chefe: talvez, depois do ritual albano, sua língua padecesse de uma espécie de paralisia, parecia-lhe ter na boca uma lagartixa morta: oh! algo absolutamente passageiro.

A lama, sempre, continuava a sair fora, paga por tarefa, até que os bondes ti intando se apinham, na cidade das reguijantes fontes.

O que quer:a, de chapéu na mão, o Rusconi? Queria interceder pelo sobrinho; mas (aquele chapéu estava engordurado como uma rosca frita) o senhor taciturno foi inamovível: o sobrinho do seu Giuseppe não era digno do tio; tinha esmurrado o seu Checco.

(27) - Lit.; Consome-se abundantemente este adjetivo, hoje em dia.

(28) - Em miúdos: o vinho dos Castelos. 
Os cavadores, ei-los, testemunhavam unânimes: os murros, mesmo poucos, tinham sido formidáveis: "O seu Checco começou a soltar sangue, sim, pelo nariz. que nem o fontalhão de Montório. Giuseppe.

“ .E tudo por uma colherada de lama. " lamentava o seu

“. Aprenderá a segurar as mãos. ”

“. .Mas aquele lá, descu’pe, por que falou pra ele morto de fome? Somos mortos de fome tanto nós como ele, acho.

O senhor não se comoveu. O seu Giuseppe deu dois ou três passos, como afastando-se a contragosto. "E depois, vai me desculpar se falo até meio boca suja mas o senhor precisa saber de tudo do jeito que foi.

“. $\mathrm{O}$ quê? "

“. Inclusive chamou a gente de bosta. E, bosta por bosta", sacudiu a cabeça "somos to dos iguais.

"É o senhor quem está dizendo!"

“ Meu Deus! Doutor! Não vai pensar que eu quis dizer. Um grandessíssimo estudioso como o senhor! Caligráfico. e tudo mais! Estava falando de nós, que estamos aqui apodrecendo de manhã até de noite. "Deu de novo alguns passos.

"Claro que a gente vai empurrando o carro. (29) como pode cada um o dele. $O$ seu Checco também não é um milionário, ora. embora, se continuar assim, me parece bem encaminhato. Cucchiara! Cucchiara!

E! sbragiava 'me 'n strascée. .(30) que o escutavam até no topo da cúpola. todos os romeiros espanhóis (31) Xingar assim um moleque só porque a gente fala cazzuola.

"Não foi só isso."

“ . Sim, senhor, está certo. Mas também o salário é de meia colher: se fosse um pedreiro acabado não receberia dois e oitenta, não é?

(29) - T.lomb. = dedicar-se a um trabalho pesado e mal pago, com obrigações familiares. Em parte alusivo, da parte do $A$., depois do que se disse do "carrinho" para o arroz.

(30) - "Berrava como um trapeiro."

(31) - Finge-se que a construção e os trabalhos fossem perto de São Pedro em Vaticano. 
Poucos passos de fora, na moldura luminosa da porta, a figura do pug.lista desenhou-se imóvel. Olhava de canto, atônito, numa expressão de pavor e raiva, onde pouco e pouco, entrou a angústia do irreparável.

"Caro Giuseppe, não há nada a fazer. Sinto muito. mas já tinha sido avisado antes.

"É para ganhar o pão. " imp'orou o tio, “ para ganhar o pão ele também, como os outros.

"Ganhará o pão em outras bandas, longe daqui. Antes, onde trabalhava?

As calças esportistas do culpado, com grandes salpicos (32), pareciam ter murchado na miséria.

Trabalhava em Trastevere, na igreja de Santa Maria, com os pintores.

"Que volte para sua Madona.

"Mas agora não tem mais nada para consertar nem para pintar, também lá, porque já pintaram e consertaram tudo, por dentro e por fora. "(33)

O senhor taciturno deu definitivamente de ombros: reviu por um instante os laboriosos mosaicos dos cosmatas e os de Pedro, os lençós brancos no sol, passou para outro assunto.

"Mas eu como vou fazer agora?" .implorou com uma contração nos lábios o jovem, como que voltado para o tio.

"Agora, meu rapaz, você se arruma, também.

E o tio fez também aquele movimento de ombros que, no seu chée, tinha sido tão espontâneo.

\section{III}

Desde os montes da Úmbria, o vento atirava água gelada a gotejar contra a luz dos cristais. Teròntola soou fracamente. no crepitar solitário da chuva. Sem cigarros-charutos, sem ninguém.

(32) - Salpicos de cimento, como pedreiro que é.

(33). - O tímpano da basílica é afrescado: vês o Cristo no trono, sete castiçais, dois anjos, um orante, os quatro símbolos dos evangelistas; na parte inferior, em mosaico, Maria, t mbém no troro, dois ajoelhados e as virgens, cinco de cada lado, como a caminhar. Embaixo, na linha das janela, as palmas: mosaico refeito. 
Um longo e monótono tilintar da sineta pontuava, entre duas rajadas, a parada, que abria uma fresta inútil no sono dos viajantes. Pouco depois, o ansiar e o rolar de um cargueiro; parecia sem fôlego, de cansaço e água, como um carregador exausto. Deteve-se na linha contígua, além da plataforma; escondeu a estação, submergiu o tiquetaque do telégrafo e das ordens. Depois a corneta, a boa. Ao partir, depois que já o rápido acumulava, num ansiar dilatado, o impulso, ouviram como ordens ou gritos, que tivessem sido inúteis.

Abriu-se a coulisse: um senhor embuçado e negro apareceu, a exigir lugar. Ȧquele tão brutal fim de corrida da porta, o novarense, acordado de pronto, sentou-se de sobressalto no divã; esfregava concitadamente os olhos. "Onde estamos?" perguntou bocejango, com a boca cheia de ameixas maravilhadas. Já condescendia ao tiel cacoete de estimação, acordado por sua vez, junto com o dono. O embuçado pareceu por um momento o fugaz cava'eiro de Heine (34) que, descido de sela, tivesse preferido o rápido.

"O vento do outono agita as árvores - A noite é úmida e fria - Envolto em meu sombrio manto - Cavalgo, só, pela floresta adentro.

Mas tratava-se de um marechal aviador, cujos cinco sentidos se patentearam magistralmente testados no Laboratório Psicofisico Central da Régia Aeronáutica, tal a presteza e a energia com que quis fechar.

Três falantes porém o sucederam, emrurrandio-se e revolvendose, hílares com o calor, e felizes. Diziam "Cá! cá! cá!"

Um resfriado benfazejo tomara conta de seus narizes e, embora três, esquartejaram-se (35) curvos e gotejantes, para guardar chapéus, jornais, horários, enquanto seguiam, a confirmação da posse, gritando "cá, cá, cá"

Tinham-se aliviado dos sobretudos encharcados; seus calçados, um tanto enlameados, revelaram-se munidos de polainas côr de rola; suas regiões cômodas floresceram com decorosa ledeza em boa casimira cinzenta, no momento em que laboriosamente debruçados se ocupava cada qual em limpar o assento.

(Vinham rajadas de chuva)

Ocupavam-nos conversares exce'sos, de que a anestesia do faro facilita aos Semideuses a evasão das lhanezas pedestres para os rei-

(34) - "Gehüllt im grauen Mantel - Reite ich einsam im Wald" H. Heine - Lyrisches Intermezzo 58, vv.3-4.

(35) - Jogo de palavras gaddiano, de gosto duvidoso. " .virada a luz. ." = girada a chave de comutação, para passar do bleu-vigília ao branco estamos-não estamos. 
nos azuis; onde, sem termos de relógio, se libertam as belas perorações do espírito, e se elas distendem a gosto, em sua amplitude imortal (36)

O que era o discurso? O senhor calado não pareceu tão pobre de fantasia nem tão desprovido de nomenclatura que não chegasse a decifrar aquelas réplicas que lhes são arcanamente caíam de boca, nobres e definitivas, saturadas de toda significação pensável (37)

Já as malas, os chapéus, os gotejantes sobretudos, como a Deus prouve pareciam ajeitados; já estavam ajeitados, assim a Deus prouve, os três cultivados espíritos; o maquinão bufava, bufava como um touro, por entre as chuvascas e rajadas, para subir até Arezzo com todos os pecaidores do trem: os que pecam em seu silêncio, gravados de chales, os que pecam na palavra; e os últimos, que, tiradas as meias, serão ao contrário os primeiros, no céu, a respirar um pouco de ar puro.

Dentro do peso das fálpebras, o senhor taciturno ei-lo que enxergava com os tímpanos (38)

Uma voz cálida e suadente, admirave'mente redonda (embora um pouco fanha) brotava dos chacoalhões do trem como a flor esplêndida e rara do poeta, quaniło se entreabre à devoção dos adeptos, envolvendo em 35 numérotés Chine, cem liras a cópia.

"A página" era o sujeito; "deve viver" era o predicado; "em si mesma" era o triunfal complemento de modo, ou maneira. Mas uma tonitruante voz (se bem que um pouco fanha) parecia o nimbo vindo dos Alpes para rescindir da primavera as flores, e os caules: "Qual página! Queria eu ver tua página, traduzida em francês! Aí, como vive? Como um f'or seca num álbum.

"Se a página alcança posição expressiva, deve desembocar necessariamente na catársis de si própria.

"Mesmo traduzida em francês?"

"A catarse é um fenômeno moral, que transcende o acidente; portanto. universal.. a práxis do fato estético, enquanto tendência, é uma tendência catárctica.

"Qual moral!. .(39) fato humano, digo eu!. "

(36) - Imortal = que não acaba.

(37) - Isto é, podiam significar tanto A quanto o contrário de $\AA$.

(38). - Recaindo ele no sono, o ouvido propinava imagens à alma embotada, tiradas como em farrapos do discurso dos três.

(39) - O sentido dissemelhante da palavra "moral" nas duas afirmações é um dos motivos típicos do arrastar-se da polêmica. 
"Necessidade, fado, tendência geral do espírito. Uma das necessidades elementares. impulsivas. E os valores éticos."

"Os valores éticos, quando não se sabe escrever, fazem cochilar Dona Eulá ia. (40) Nice, indignada, protesta contra o vilão. "E disse ah! mancator di fé, marrano!"

"Envergonhem-se! " trovejou o nimbo; "envergonhem-se!" $\mathrm{Pa}$ recia mesmo a má trompa quando há-de mugir por sobre as nuvens negras, e a espada do arcanjo há-de vir rebrilhando scbre nosso castigo, impelidos para eterno compungimento (41)

"Envergonhem-se! Chega! É hora de parar! Chega de exercícios de caligrafia, da composiçãozinha das lembranças da infância, da lírica dos três gerúndios, do aforismozinho pata de mosquito.

E hora de parar. Essas lagartichazinhas anêmicas, olha só, que se quentam no meio-sol!"

O homem de Novara, estarrefeito, compreendeu imediatamente que não falavam de rufos ou de tampas de bueiro. O trem subia seguro, num resfolegar violento, os braços das bielas venciam a grav.dade das coisas, o açoite do vendaval. O homem sem sapatos, todo cuvinte, movia placidamente os dedos dos pés dentro de seu envoltório.

Em sincronia com o bater dos trilhos, as joviais trajetórias de seu pescoço de elevada periodicidade tendiam grandessíssimas ore'has ao encontro da catarse e do ritmo, da página quintessenciada e da humanidade das personagens. da escritura e da dialética, de "todo um mundo" vivo em Rostoff e dos "onanismos caligráficos" ao contrário, de Pico Ponza; grandessíssimos ouvidos ao encontro da virgulinha, da palavrinha, do soluço, do som do tom, da cor, do sabor. Depois vieram a linfa, a vida, a palpitação, e de novo a estética; depois a ética ocidental, o Cristianismo. a arte, os colhões duros, o barroco, o romance, a lírica, o filme. Aos heróis retóricos e classicizantes do vácuo Bartoloni foi contraposta a figura maravilhosamente complexa de Catarina Pisto owna Bigolaiewnska, preceptora sádica do órfão epiléptico e tubercolótico Tchiusquin (oh! aquela

(40). - Dona Eulália, (aquela que tagareja com jeito, do grego laléo = eu tagarelo, eu digo elegantemente) é uma das mais deliciosas "femmes savantes" do grão século: mas não obstante tudo, quando lhe puseram entre as mãos a Ética Nicomaquéia, dormiu-lhe em cima às primeiras linhas. Nice é a bela suga-romances, que deles tira a água e o açúcar (por assim dizer): o felāo é quem, de um jeito ou de outro, engana a vencedora. O endecassilabo é o conhecido endecassílabo ariosteco.

(41). - Ablativo absoluto: "sendo nós impelidos, etc." Tem a aparência de uma "constructio ad sensum" mas não é. 
cena da mão na calça!) personagem extremamente adivinhada, essa também, expulso aos 23 anos das fileiras do exército por alcoólatra e beberrão indefectível, finado depois de disenteria perto de Nishnij-Novgorod, ao contrário do comum dos bibedores que, na Itála, têm intestinios de aço.

Não quererão ignorar as abismais contradições da alma russa!

Ouviram-se estrondos distantes: estampidos de cal. 381 nas escarpadas encostas do Hermada. "Croce é Croce!" - A estética pura!", "O livro amarelo!" "O documentarismo" E depois, ainda, o fogo tamborilante do Mundo, da Autofiguração, da Catársis, da Transfiguração, do Advento (do novo romance) Pareciam os títulos mais altos do baralho de taroques, como "Adão e Eva", "A Criação", "A Morte", "O Juízo Universal" (42)

Rápidos na tela timpânica, arrebatados pelo sopro do furacão, passaram naquelas vozes Valmichi e Aquiles, Menelau corno e a não-existência de Homero; as sete cidades natais deste e a tragédia sofocleana, a némesis e o fało, a Graça e o livre alvedrio, os primitivos senenses e Ada Negri, a Jovem Parca e os capões de Renzo, a Comédia Humana e ю Tempo Perdido; sem contar os Karamanzov, os Rougon Macquart, os Vela, os Nibelungos, os Malavoglia, os Bencivenga, e a autob.ografia de Garibaldi.

Então, a conversa tomou o rumo do Janículo; e da nova estação de Santa Maria Novèa.

Depois de alguns considerandos sobre o espigão janiculense, (como todos os espigões ele tem função de divisor de águas) deplorou-se o escasso sentido novecentista da família Garibaldi. cujos cavalos. o que diria deles um criador de classe? um De Chiri$\operatorname{co}$ ? (43)

O da senhora, então! Está certo que ele ande um pouco exagitado, como mostram a crina e as narículas, mas é esse o modo de decolar? Nem mesmo em Marena, na cria. Tamanhas berinje'as!.

(42) - Nenhuma alusão aeventuais títulos de obras vivas, mas pura e simplesmente aos títulos dos chamados "taroques"

(43) - Giorgio De Chirico, pintor francamente admirado pelo A. tem toda uma série de telas Egeu-arqueológicas, ocupadas por certos cavalos sui generis, que em Florença os chamam "i "avallini di De Chirico" Do mármore pentêlico dos quadrijugos soltos por incêndios e milênios fora, fá-los retornar epì zìni zalàsses, o retornante sonho do metafísico. 
Ao contrário, a estação de Florença etc. etc.

E concluíram que o fontalhão de Papa Paulo era um velho despautério, retórica de tempos idos, frente ao humanismo do novíssimo pacotão.

"Vejam só, a água autêntica, a água potável. a que se bebe todios os dias em família, assim. ., humanamente, ao voltar para casa esfalfaidos do trabalho. suados, estafados, gastos, os pés enlanguecidos.

"A água Pia, queres dizer "

"Ou mais precisamente. a água Márcia."

"Vejam se ela faz tanto a'arde de si mesma,. como esta, Pia ou Márcia que seja!.

"Priscis Romanis novisque jocunda, E consule Marcia, e pontifice Pia (44), vai permeando tácita as inúmeras veias da Urbe.

"Como és falso!. Falasses antes que ela chega sem retórica à torneira da cozinha .

"Com o conta-gotas.

" e esta outra" (inchava o toráx) "tem necessidade das aparências, da epígrafe de Papa Ottoboni, do Borghese, com águias, e dragões.

O senhor sem língua reviu então o reservatório que recebia o rio, e este, que saía como inesperado nos cinco tombos canutos, nascido de um profundo e misterioso decoro, de uma atitude peremptória, de uma certeza sistematizadora.

Nem um pilar ou uma gota havia ou caía vã ou falsa, enquanto tudo parecia vaidade na terra, e vaidade a sarna (45)

(Eis, a um tiro de chassepot das urtigas do protomártir (46) o desmedido e firme desígnio: e o céu de pedra da Cátedra)

(44) - Da epígrafe que contorna o novo reservatório de Villa Borghese para a Água Pia ex Macia.

(45) - Pol. - Sentido aproximativo: "O catolicismo papal, a exemplo do tom augusto e peremptório de Roma, (veja-se alhures "o rigor executivo de Roma") acolhe o rio para nós sabidinhos inesperado na magniloquente "mostra" (t. técnico) do Fontalhão: que infunde sentimentos de respeito e quase de temor assombrado para com o Poder sistematizador. A sarna, ou seja a miséria, se ininterruptamente dela usas como ostentação e bica, é vanitas vanitatum não menos que os pavilhões barrocos de Paulo V"

(46). - A trinta passos da igrejinha de Santo Estêvão Protomártir e nos lugares do martírio apostólico onde a urtiga viçava livremente, ergue-se e estende-se o desígnio (imenso) da Basílica e da Cúpula, e é esta como um céu de pedra para a Cátedra. 
O vendedor de cartões te implora, por uma lira mandarás lembranças a vinte parentes, com Roma toda! O tanque, em torno, os garotos-demônios so'tam nele gritando suas caravelas de papel, os joelhos arranhados sobre a pedra e as impelem numo à sua sorte. Servas e granadeiros, nos dias de folga, olham extasiados. seu fragor $(47)$ e, afastando-se nas alamedas, às horas da noite, todavia os seguem os líquidos murmúrios, o ciciar perene. Arcana músi$\mathrm{ca}$ ! (48)

Roma doura-se: brancas redondas nuvens atravessam os céus: aladas vitórias e quadrigas procorrem como céleres ventos, voam segundo as chama a Flamínia (49): dão vermelhas luzes os vidros; da telhagem insurgem antigas as torres e paços, quase comunidos castelos. - E o instante áureo que em seu fogo deles os espíritos magnos reviram, na panelinha do mundo, a fritadela do conteúdo (50) O mocinho quarentão exercita-se, caligrafeja; mas de quatro cálamos não um jorra palancas. O prêmio evapora (51)

$\mathrm{Na}$ rua Balduína, na rua Scaccia, e passado o arco dos Castanheiros, algumas personagens do Romance Novo que aí fazem morada esquecem-se regularmeente de pagar os impostos. E acontece o mesmo nos barrancos entre os capins e caniçais densos onde (aos de colher (52) as latas esquartejadas thes dão entrementes seu abrigo e seu ferrujoso teto. Depos, ao estremecer da noite, onde marca o céu prateadas esperanças e quase o presságio do mar (53),

(47). - " Olham seu fragor. " Não um jeu de mots, mas expressão do real désarrois psíquico (idiotia venerans) de quem observa um ferîtomeno de aspecto grandioso e, a um só tempo, fragoroso: como é, por exemplo, o Niagara, onde leva seu tombo.

(48). - Arcana é adjetivo tirado de Barilli, magnífico melodramista, e com inteiição Barilliana.

(49) - As Vitórias e as Quadrigas do Vitoriano abrem o voo e a corrida na direção da Flamínia. Era a estrada das Gálias, que se abria proficiscenti in Arimi num. "Quase comunidos castelos" é al. às construçōes de aspecto de fortaleza, como a Torre das Milícias e o Palácio Veneza.

(50). - " Os espíritos..."; isto é os giandes escritores em geral, vistos em sua quidditas profética. O A. incluiria vaidosamente a si próprio? Vá lá adivinhar.

(51) - Quatro cálamos, (cálamo = caneta de pena), ou seja, o engenheiresco, o filosófico, o narrativo e o doméstico natalino.

Palanca,t. lomb. = tostão; e genericamente grana.

(52). - Desde que os pedreiros (os de colher) fazem casas onde não as há, aloiam-se por vezes num barraco ou maloca perto da construção, inclusive pa'a vigilância noturna de seu local de trabalho.

(53) - Ou seja, para ocidente. Acha-se o litoral a ocidente de Roma, e disto deriva, em seu céu,com o por do sol, uma espécie de claridade marinha. Perseguindo a última luz, o olhar dos amantes fixa-se onde está a estrela Vés"er "Frateadas esperanças" da lua sobre o mar, é uma fantasiosa metciímia gaddiana, que cuidarás rão reproduzir. 
lá se quedam, ocultos a beijar bocas nas grandes sombras dos pilares e dos vultos, ou, afastadas as urtigas, entre o povo amado e imperscrutável dos caniços (54); ou na jângal das desavergonhadas alcachofras. E aqui acaba que eles esquecem até mesmo dos meganhas. A lei, toda lei, docemente evapora, como um castigo que seja perdicado; ou como o prêmio fa hado.

$O$ toque do ângelus, da torre de Santa Maria in Trastevere, poderia chegar-lhes nalma e inverter-lhes o desejo, se na basílica tivesse um sineiro dos cacetes como em Brianza. Mas tudo cala, ou tudo murmura, debaixo da palpitante estrela de Roma (55)

Novo rolar não previsto. Novo fim de percurso da coulisse, peremptório e malcriado. Foi depois a cortina que se afastou. Arrastadas sobre a barra, as argolas de latão tinham tilintado, como para uma flébil advertência. Mas era um emaranhado de vozes e de func.onários que traziam para dentro alguém, perguntando, por assim dizer, se havia lugar. "Aqui tẹm lugar, aqui; cavalheiros, levantem-se!. " Os três funcionários de Par-naso disseram que não de plenos narizes, escandalizados pela intrusão, que se revelava sem precedentes na história das estradas de ferro. Mas o o har de um soldado os deixou mudos, e mais quanto depois apareceu e que viram depois todos, inclusive o senhor taciturno e inclusive o hidráulico, no circuito em oito de seu destino à repetição (56)

Todos se levantaram e colocaram-se o mais possível de parte. Um assento inteiro ficcu livre. As duas meias do engenheiro, com dentro os dois pés, arrastavam-se semi-secas sobre o linóleo, enquanto os sapatos acharam-se subitamente ao léu entre os pés de todos. "Porca miséria" disse, aliás, o mais desajeitado dos carregadores, tropeçando neles bundatrás.

Aquele que puxavam para dentro parecia um morto. Um soldado segurava-lhe agora a cabeça, os braços caíam, enquanto o carregador principal o tinha como que abraçado para encostá-lo.

(54) - Não se enxerga por entre eles; a tal ponto é denso o caniçal, e pois caro aos amantes.

(55) - Os tímpanos sensíveis do A., ocupado nos quatro cálamos, fazem que aborreça certos sinões nouveaux-riches. Alhures, o sino o consola, quando manda, piedoso e modesto, "toques de longe".

(56) - Até nos mais graves momentos é dominado pelo tique. Seu pescoço descreve um oito arqueado, uma lemníscata arqueada. A lemníscata plana, descoberta por Giacomo Bernoulli, é uma curva de $4 .^{\circ} \mathrm{grau}$, em forma de $B$, expressa pela equação:

$$
\left(x^{2}+y^{2}\right)^{2}-2 a^{2}\left(x^{2}-y^{2}\right)=0 .
$$


Puseram-lhe duas almofadas brancas debaixo da nuca, imediatamente oferecidas pelos passageiros. Estava descorado no rosto; um fio de sangue vinha-lhe pelo canto da boca, tinha pingado no soatho e gotejava agora no divã.

Esticaram-no com cuidado; mas é que os sobressaltos do trem faziam ba ançar aquele cansaço grave, que nâo tinha revides. Ensopado de água, esteve vestido de ciclista. Um ciclismo de pouquíssimo preço.

Estava fora inclusive uma senhora assustada, e inclusive o marechal-piloto; jovem, sem manto, os galões não tinham mais o condão de militarizar a expressão angustiada de seu rosto.

Tinham esticado o exânime sobre o assento, a cabəça entre as almofadas alvíssimas; um improviso de enfermaria; e agora, ao se retraírem. topavam todos, um após o outro, nos onipresentes sapatos. Mas o senhor taciturno o reconheceu com uma pontada no coração: "O sobrinho de Rusconi!" constatou mundo.

Era o jovem páliđo, que viera a ele ouvir a sentença atrás do tio e prostrar-se no desespero depois de presentear com tamanhos socos o seu Checcho.

Ainda o via, como no dia antes, no retângu o áureo da porta, no fundo da últ:ma claridade, quase a chorar por pão!

“ Desceu. sim, em Teròntola. "

“ Quis embarcar de novo que o trem já estava com velocidade. conseguiu tomar o trem por milagre. a última porteira do carro de cauda. isso?"

"Esta bem, mas que diabo fez depois. para arranjar

" A cauda do trem de carga, Chefe"

“ O mesmo de sempre! Parado no desvio com sua bela quina no jeito! .o perfil. escapa por meio centímetro" (57): e marcou a medida com o polegar, sobre a extremidade do indicador.

“ Que nada, Chefe, dava para passar muito bem. mas com a porteira aberta. é claro que.

(57). - Se a quina do carro de cauda for deixada perto demais da agulha (do desvio) pode incidir no perfil da linha contígua. Perfil, t. técnico, é o polígono imaginário que delimita a secção de respeito do móvel por parte do mundo: e do mundo por parte do móvel. 
“. Bateu com a porteira na cabeça dele. "

que subiu? Hã!. Mas entâo como é que ele conseguiu? Comø é

". .Não! E'e já estava em cima, ia fechar. deve ter sido bem no momento em que estava se debruçando para fechar

“ .Ficou prensada no meio, como numa morsa! Meu Deus! Olhem só com'o ficou!.

Somente então o senhor observou, do outro lado do rosto e da cabeça, uma abrasão arrepiante, em que, no vaivém, não tivera oportunidade de reparar. O ouvidø, os cabelos, o pescoço estavam empastados de sangue vivo.

“ Mas o senhor, desculpa, por que nâo mandou parar? Po: que não puxou o alarma?

"Alarma? Mas eu na hora não estava lá! Foram dois passageiros que fecharam. Talvez achassem que ele estava só ferido. Caiu em cima deles.

" .Está bem, vamos fazer o relatório. Onde estão esses do:s? Mas fora daqui, pelo amor de Deus. Onde estão? Procure-os. " Procurava o livro e o lápis.

"Mas que? Que dois?"

“ Os que o socorreram primeiro. Ah! Aqui está a carteira. " exclamou, apanhando-a. e enforquilhou os óculos: “ .Ah! E estes são os documentos. Tome. "; e devolveu tudo à soldado. "Aí tem os dados pessoais? Veja. Achou? Tem endereço?

"Sim, Chefe, tem esta folha de papel, a lápis. Cascina Garo'fa", leu em voz ampla e clara; "Carolina Roncoroni, viúva Rusconi.

"Quem é? A mãe? "

"Acho que sim. Ele, aqui está a identidade, chama-se. chama-se aqui está. Rusconi Carlo, filho de Gerolamo, falecido, e de Carolina Ronconi, nascido em. Cascina Mornaga, no dia 29 de julho de 1914. Tem uma passagem de terceira classe até Milão. Aqui tem uma foto. um artilheiro de montanha, de bigodes.. "voltou-a: "2.0 Regimento de artilharia de montanha, 36." bateria. Rusconi G.; embaixo tem uma cruz.

O Chefe escrevia, escrevia.

“ Mas não tem um médico neste trem? " 
"Procuramos de ponta a ponta, Chefe; ninguém. "

"Pois bem, deixo com o senhor e com os dois militares. Assim que chegarmos a Arezzo. cavalheiros", disse, voltando-se: "queiram passar para outric compartimento. tenham a bondade, por favor mais na frente há lugar. as bagagens podem deixar", e escrevia, sempre, na caderneta.

Mas por que diabo deu na cabeça dele de descer?

"Sei lá! Procurava alguma coisa para comer, disseram. Diz que não podia mais de fome. Até aí ele tinha agüentado. Não queria gastar, não sei por que. Voltava para ver a família.

"Na carteira, quanto tem? Veja o senhor, Zano'etti, vamos precisar pôr no relatório isso também.

"Mas. nada, Chefe." sidoras.

"Olhou bem?" Ergueu por cima dos óculos duas pupilas inqui-

"Nada, nada."

O agente tirou da carteira uma pequena folhinha de cabeleireiro, que desdiobrou e que se revelou impressa em tipos pretos. Entrou a percorrê-la e depois de lê-la à meia voz, como se procurasse aí uma motivação do ocorrido.

، Depois de um forte desgosto que vos darão vossos inimigos, e depois de ter sofrido um forte golpe, encontrare:s finalmente a paz, por causa de vosso nobre coração, que foi sempre muito nobre e digno de honra, e depois desta circunstância todos vos respeitarão e vos deixarão feliz e tranquiilo, e a Sorte não deixará mais de proteger-vos, sobretudo se tiverdes jogado nos números 29-7-14"

"E o cartão postal?" Perguntou um dos soldados.

“ Ah! está aqui, tome. "; e o agente leu, aqui também à meia-voz, decifrando com alguma dificuldade a caligrafia: ra.

“. À gentï senhorita Clotilde Ramazzotti Lonate Baffalo-

"Pobre diabo! Até noiva e'e tinha! Com essa dose de miséria nas costas!" Mando-lhe felizes votos de Natal e muitas caras lembranças do seu C.R." - E olhem para ele agora!" Olhou-o de vertade.

Alguém estava passando mal no corredor; o homem de Novara, abaixado a procurar os sapatos, estava a ponto de apanhar um 
e chorar nele. O senhor taciturno olhou no divã aque'e rosto abandonado (os olhos abertos e imóveis!) onde já não estava esperança ou cólera, aquele frio vermelho que ninguém ousava enxugar: compreendeu que a discussão sobre o conteúdo e sobre a página sofreria uma interrupção.

Um dos soldados, com mão piedosa, quis fixar aquele rosto que os sobressaltos e o ímpeto do rápido arrancavam cruelmente à imobilidade.

Verde Lombardia! Onde já desceu a névoa, e as desoladas neves. A colher denomina-se aí cazzuola e o tijolo quadrello. O pão de Como não é para todos; é preciso vagar, andar! Construir-lhes igrejas aos Dándolo, aos Sermoneta as casas.

Os enforcados tiveram túmulo; mas os que morrem de fome onde irão dar? O seio da mãe não pode recebê-los de volta.

As bielas transformavam em desesperada corrida o impulso; com silvos entre os vales escuros, o rápido arrastava cada qual para o seu acaso; a polêmica da colher tinha sido mais dura que a outra. E cada qual, depois da rixa, queria voltar a abraçar a mãe. Talvez as três peças bastassem! Com as calças no fio, com a carteira gasta até a tela. Oh! A cozinha era fria, já sem cobres e vozes, na sombra sobre a lareira Pódgora e Mrzli (58) e o artilheiro abaixado na direção das sombras, labutando com sua carga, como no Calvário. Oh! mas a mãe!

Essa lhe faria festas mesmo sem dinheiro, o beijaria e beijaria assim mesmo, chorando,. a velha. Carolina Roncoroni viúva Rusconi .

\section{Explicit "IL CASTELLO DI UDINE"}

Absint inani funere neniae

Luctusque turpes et querimoniae.

(58) - Em frente à lareira, algumas fotos de guerra. " . sua carga, como no Calvário. ": os artilheiros e os alpinos, puxando por meio de um cabo as peças, sobre a montanha coberta de sombras pela noite, lembravam a figura do Homem, curvo sob o peso da Cruz. 